\title{
Pożytki z czytania nekrologów. Sprawa Pika Mirandoli
}

Twórczość Franciszka Pika Mirandoli popadła w zapomnienie. Specjaliści wracają do jego dekadenckich liryków z obowiązku, mało kto zna jego prozę artystyczną, mimo wznowienia Tropów i okrzyknięcia ich zwiastunem surrealizmu i fantastyki literackiej. Nawet w roku obchodów setnej rocznicy odzyskania niepodległości nazwisko Pika nie wybrzmiewa z częstotliwością, na którą zasłużył choćby zbiorem opowiadań Tempore belli oraz autorskimi opracowaniami materiałów historycznych poświęconych Pierwszej Brygadzie Legionów. Zupełnie też wypadły z krwiobiegu kultury polskiej jego utwory polityczne: wiersze, artykuły prasowe, krytyka literacka.

Pik był nieobecny już za życia. Podzielił los pokolenia Młodej Polski, którego przedstawiciele w wolnym kraju odsunięci zostali na margines. Kogóż mogły obchodzić dekadenckie dylematy duszy, gdy zadanie odbudowy Polski podjęła następna generacja? Nie zważano, że Mirandola w roku I9I8 nie był już piewcą smutku wewnętrznego. Takim go jednak pamiętano i tym usprawiedliwiono lekceważenie. Jedyna książka poświęcona Pikowi ukazała się wkrótce po jego śmierci w 1933 roku z inicjatywy 
środowisk aptekarskich ${ }^{1}$ Jej autor, Janusz Herlaine, zdając sprawę z motywów zainteresowania pisarzem z Krosna, dzieli się opiniami kolegów, których rozpytywał o Pika:

Gdy się zwierzyłem jednemu z kolegów z zamiaru zapoznania się z Pikiem, zebrania cenniejszych utworów i przekazania, jako wiatyku dla udających się w najdalszą drogę całkowitej zagłady, odpisał mi: „Strasznie mi Pana żal za tego Mirandolę. Uważam nawet, że Pan tej pracy nie powinien był przyjąć. To jest autodeprecjacja. Stanowczo powinien Pan inaczej sobą gospodarować. Ta wiadomość od Pana o Io arkuszach życia i twórczości - nieważnych, to, naprawdę, przejęło mnie smutkiem”.

Inny starszy kolega rzekł: „Zazdroszczę, bo to szlachetna, piękna postać naszej literatury" ${ }^{2}$.

W sprzeczności tych opinii odzwierciedla się odmienność pojmowania zadań stojących przed historykami sztuki. Wynika ona z różnicy postrzegania istoty procesów kulturotwórczych. Dla jednych budowanie kultury to proces ciągły, zależny od przeróżnych uwarunkowań, będący efektem nawarstwień się elementów o różnym okresie trwania, w którym żaden szczegół nie jest bez znaczenia, a Mirandola okazuje się „piękną postacią literatury”. Według innych kultura dokonuje skokowych postępów na drodze wyznaczonej przez kamienie milowe - arcydzieła, więc tym, co wypełnia przestrzeń między wielkimi krokami ludzkości, np. twórczością krośnieńskiego aptekarza, zajmować się wolno w drodze wyjątku i tylko ze względu na wielkich. Można by w nieco kaznodziejskim tonie pytać, czy dziś zajmowanie się Pikiem to strata czasu czy zadanie godne pozazdroszczenia, jednak w Piku, jako problemie historii literatury, tkwi coś innego. Mirandola nie był zwykłym umiarkowanie utalentowanym wyrobnikiem. Czy był geniuszem? Tego też powiedzieć nie można. W swoich poszukiwaniach podążę więc za Herlainem, który problem ten rozwiązuje, stawiając paradoks istnienia Pika:

Zacząłem go szukać w literaturze... u Chlebowskiego, u Chmielowskiego, u Lama, u Brücknera, śród portretów Dębickiego i Galińskiego, lecz na próżno. Jeśli gdzie co spotkałem, były to wzmianki nic nie dające, a jednak przesądzające sprawę. Stało się jasnym: Mirandola nie istniał. Był mitem, o którym chodziły sprzeczne wersje³.

Próby odnalezienia prawdy o Piku nie podjęto w latach trzydziestych, choć jego śmierć była wstrząsem autentycznym. Po drugiej wojnie światowej złożono Mirandolę na ołtarzu duchowi czasu, który domagał się ofiar. Lewicowe poglądy Mirandoli zostały zdyskontowane na rzecz urzędowej wykładni procesu kulturowego: Pik był

1 Inicjatorem powstania tej książki był redaktor „Wiadomości Farmaceutycznych” Franciszek Herod (patrz: A. Chodkowska, Franciszek Pik-Mirandola-Przyczynek do biografii niepokornego aptekarza - poety, „Kwartalnik Historii Nauki i Techniki” 2009 (R. 54), nr I, s. 172.

2 J.L. Herlaine, Franciszek Pik Mirandola pieśniarz mitości i niedoli, Warszawa 1933, s. 8.

3 Tamże, s. 8-9. 
pisarzem socjalistycznym, który zmarł w nędzy, tyle oficjalnie, dorobku jednak nie opracowano, wydania dzieł zebranych nie zlecono.

Dwadzieścia lat później Jacek Trznadel stwierdzał: Nazwisko Mirandoli jest dzis dla przeciętnego znawcy naszej nowszej literatury dźwiękiem prawie pustym i, jeśli chodzi o jego prace literackie, kojarzy sie jedynie z przektadami prozy francuskiej, skandynawskiej ${ }^{4}$. Rzeczywiście, paradoksalne, mityczne istnienie Pika przybrało nową postać. Za sprawą tłumaczeń baśni Andersena, utworów Kiplinga i Defoe, Pik otwiera drogę do literatury kolejnym pokoleniom. Mirandola pozostaje obecny w roli tłumacza wielkich dzieł literackich swojej epoki, przekładał bowiem utwory noblistów, klasykę literatury światowej, dziś często zaliczaną do kanonu lektur szkolnych. Sam jednak pozostaje w cienius.

Od pewnego wzmożenia zainteresowania Franciszkiem Pikiem związanego z setną rocznicą urodzin, mija niedługo pół wieku. Tak długie zniknięcie Mirandoli z radarów historyków literatury samo w sobie jest powodem, aby spojrzeć na krośnieńskiego poetę ponownie. Wydaje się ono też dobrą okazją do weryfikacji trwałości wartości kulturowych reprezentowanych przez Pika, czy, mówiąc słowami Herlaine’a, sprawdzenia sensu mitu Mirandoli.

\section{Co mówi Nowy Korbut}

W wieku XXI mity weryfikuje się cyframi, dlatego sięgam po Nowy Korbut. Twórcy bibliografii narodowej spełniają swój obowiązek, nie oglądając się na koniunktury rynku literackiego i giełdy historycznoliterackich wartościowań. Ich benedyktyńska praca wydobywa i gromadzi fakty. Hasło osobowe Franciszka Pika Mirandoli, zgodnie z porządkiem przyjętym w Nowym Korbucie, zawiera zestawienie najpierw twórczości własnej, w tym też przekładów, po czym następuje bibliografia przedmiotowa: opracowania ogólne, recenzje poszczególnych utworów, recenzje przekładów. Spojrzenie na uporządkowany w ten sposób dorobek Mirandoli unaocznia dwa problemy. Po pierwsze pozwala ujrzeć w perspektywie czasowej i w odpowiednich proporcjach twórczość autorską i działalność przekładową Pika, po drugie umożliwia weryfikację sądu o zupełnym już za życia zapomnieniu tej postaci życia literackiego.

4 J. Trznadel, Franciszek Mirandola, [w:] Obraz literatury polskiej XIX i XX wieku, red K. Wyka, H. Markiewicz, I. Wyczańska, Seria V, Literatura okresu Mtodej Polski, t. I, Warszawa 1967, s. 775.

5 Należy jednak oddać sprawiedliwość autorom nowszych publikacji poświęconych Pikowi, a niecytowanych w tym artykule: Piotr Kitrasiewicz, Franciszek Mirandola. Nadzieja i przekleństwo, [w:] tegoż, Pisarze zapomniani, Warszawa 2007, s. 26-36. Dorota Samborska-Kukuć, „I zdaje mi się, że mię wiatr rozwiewa”. „Liber tristium” - debiutancki tomik Franciszka Mirandoli, „Ruch Literacki” 2017 (R. LVIII), z. 2 (34I), s. I5I-I62; Łukasz Kucharski, Wartości czasu Wielkiej Wojny w opowiadaniach „Tempore belli” Franciszka Pika-Mirandoli, [w:] Między pamięcia a projektem przysztości. Doświadczenie historii w literaturze polskiej lat I9I4-I9I8, red. D. Kielak, M. Makowska, J. Niewiarowski, Warszawa 2016, s. I47-158. T. Łebkowska, Franciszka Pika Mirandoli tropienie wolności, „Ruch Literacki” 1982 (R. XXIII), s. 3-4 (I32-I33), s. 135-I43. 
Rozpisanie dorobku Pika na osi czasu obrazuje ewolucję jego zainteresowań artystycznych - choć określenie to użyte jest tylko umownie. Listę prac własnych otwiera późny debiut poetycki w wieku dwudziestu siedmiu lat, po którym następuje zbiór liryków z I9O roku - ostatnia książka poetycka Mirandoli. Po lirycznym preludium na scenę wstępują dzieła dyktowane przez historię: najpierw ożywione duchem 1905 roku: szkic Sztuka a lud oraz utwory dla najmłodszych zebrane w Latarence. Podarku dla dzieci robotników polskich. Z wojennych doświadczeń czerpią zaś zbiory Tempore belli oraz opracowania reportażowe przezroczy upamiętniające walki Pierwszej Brygady. Ta ostatnia grupa mogłaby być też pierwszą pozycją, którą zaliczyłbym do ostatniego etapu twórczości: do kuriozów i dzieł produkowanych z myślą o zarobku. Jakże inaczej traktować wydawane po odzyskaniu niepodległości utwory dla dzieci, Wielki arabsko-egipski sennik lub Jak winszować. Zbiór powinszowań?

Oczywiście, owe trzy fazy twórczości, będące zaledwie konstruktem interpretacyjnym, nie mają wyraźnie wydzielonych granic, stanowią raczej okresy kulminacji pewnych tendencji nakładających się na siebie. Trudno w takim schemacie jednoznacznie umiejscowić zbiór prozatorski Tropy, wydany w postaci książki w I9I9 roku, zawierający jednak krótkie utwory publikowane w czasopismach w latach I9IO-I9I8. Miejsca też dla siebie szukać musi jedyna powieść Pika Przygoda profesora, opublikowana w „Nowej Reformie” w I9I6 roku (inny tytuł: Dusze w ogniu). Jeśli warto taki model konstruować, to ze względu na pożytek poznawczy z zestawienia dat publikacji i ich typów z wiedzą o biegu życia artysty.

Młodość i dzieciństwo Franciszka nie zapowiadały trudnego życia. Urodzony w dostatnim domu jako pierwszy syn z dziesięciorga rodzeństwa mógł liczyć na objęcie rodzinnego interesu: dwóch aptek w Krośnie i dzierżawy sezonowej apteki w Iwoniczu. Jednak śmierć ojca w I887 roku rozpoczęła okres powolnego, ale nieuchronnego ubożenia rodziny. Zdarzenie to wpłynęło na losy młodzieńca, który musiał przygotować się do szybszego przejęcia obowiązków głowy rodziny ${ }^{6}$. Zdołał jeszcze za własne pieniądze odbyć studia filozoficzne na uniwersytecie w Heidelbergu, Berlinie i Paryżu, jednak sytuacja zmusiła go do objęcia posady w aptece niegdyś prowadzonej przez ojca, mieszczącej się w kamienicy, która do niedawna była w posiadaniu jego rodziny.

Kontakt z wielką kulturą europejską, pobyt w metropoliach tętniących sztuką, inspirował do własnej pracy literackiej. Jej efektem były dwa tomy wierszy, o których Wilhelm Feldman pisał, że „oderwane są od życia”.

W wiek dwudziesty Franciszek Pik wchodzi obarczony koniecznością zarobkowania niezgodnie z powołaniem artystycznym. Dochodu szuka w wyuczonym zawodzie jako dzierżawca aptek w Korczynie (1902-1909), Bukowcu (1909-1912), Łącku (I9I2-I9I3) i Stryju (I9I3-I9I5). Ostatnią aptekę pragnął objąć w Tymbarku - starania

6 Zgodę na odbycie praktyki aptekarskiej otrzymał w drodze wyjątku po piątej klasie gimnazjum (patrz: Jan Tulik, Cichy i wielki. O życiu i twórczości Franciszka Pika-Mirandoli, [w:] Literackie Krosno, red. J. Kułakowska-Lis, G. Przebinda, Krosno 2016, s. I52.).

7 W. Feldman, Piśmiennictwo polskie ostatnich lat dwudziestu, tom 2, Warszawa 1902, s. I44. 
w tym kierunku podjął w I9I7 roku, otrzymał pozwolenie rok później, zaś rozczarowany jej nierentownością odsprzedał ją w 1926 roku po kilku latach puszczania jej w dzierżawę z myślą o stałym dochodzie zapewniającym zabezpieczenie na starość ${ }^{8}$.

Jednocześnie Pik próbował utrzymać rodzinę z pracy etatowej. Przed wojną był na posadzie sekretarza w fabryce przyrządów i narzędzi wiertniczych, od I9I5 roku w Urzędzie Odbudowy Galicji, od I92I w piśmie plakatowym Konczyńskiego. W międzyczasie redagował „Żeglarza Polskiego” oraz „Ekran”. Obraz życia Pika będzie pełny, gdy doda się jeszcze próby opatentowania wynalazków z dziedziny muzyki i chemii, oraz ryzykowne inwestycje w przemysł naftowy9.

Dzieląc życie między role prowincjonalnego aptekarza i miejskiego urzędnika, Pik Mirandola walczył o swoje powołanie literackie. Czas był niestabilny, najpierw rozruchy 1905 roku, potem wojna i lata odbudowy. Linia życia w tym okresie schodzi z wyżyn czystej poezji i biegnie gdzieś między twardym obowiązkiem utrzymania siebie i rodziny, a linią dziejów, od której nie sposób było się uchylić. Wypadkową tych napięć jest okres powstawania utworów tematycznie bliskich życiu społecznemu i historii.

W 1922 roku, dzięki poleceniu przez Stanisława Lama ${ }^{\text {Io }}$, nawiązał współpracę z wydawnictwem Webera w Poznaniu i postanowił głównym źródłem dochodu uczynić pracę przekładową. Liczba stron tłumaczonych w ciągu roku od tej pory będzie liczona w setki. Wcześniejsza działalność translatorska wydaje się wobec tego okresu czymś zupełnie innym, także jakościowo. Przed rokiem 1922 jako osobne pozycje książkowe Pik przełożył około dziesięć powieści, zatem, statystycznie, nie więcej niż jedną rocznie. Daty wydania wskazują, że mowa o dwóch krótkich okresach intensywnej pracy przekładowej: I905-1907 (siedem powieści) oraz 19I4-I9I8 (dwie). Daty te świadczą o nasilaniu się działalności translatorskiej w czasie okresowych pobytów w mieście, gdzie praca przekładowa stawała się istotnym źródłem utrzymania. Niemniej jednak tonację główną nadawały dzieła świadomie wybierane (Zola, Geffroy), w tym przekłady liryczne (Novalis, Verlaine, Laforgue), które nie były dochodowe.

Decydując się na porzucenie aptekarskiego fachu, nie zabiegając o posady państwowe zabezpieczające spokojny byt, Mirandola wydał się na pastwę chciwości wydawców. W roku 1922 ukazują się jego przekłady Maeterlincka (Inteligencja kwiatów, Życie pszczót), Rollanda (Colas Breugnon), Goethego (Cierpienia mtodego Wertera), France'a (Poglady ks. Hieronima Coinarda), Bjørnsona (Synnøve Solbakken), Kiplinga (Księga dżungli), Spittera (Imago), Tagore'a (Noc ziszczenia). Tempo to będzie utrzymane aż do śmierci i nawet jeśli liczba woluminów określona przez Płomieńskiego na 200 jest przesadzona ${ }^{\text {II }}$, to wyobraźnia podsuwa obraz katorżniczej pracy. W tym

8 Por. A. Chodkowska, dz. cyt., s. 173, I77.

9 Największy zasób informacji na temat technicznej inwencji Pika i jego związków z przemysłem naftowym zawiera artykuł Jerzego Pileckiego Franciszek Mirandola i Jan Szczepanik. Dialog wyobraźni technicznej i artystycznej, „Studia i Materiały z Dziejów Nauki Polskiej”, seria D, z. 4 (I963), s. 5I-88.

10 Herlaine, s. 27.

11 Liczbę tę Płomieński powtórzył kilkakrotnie w swoich publikacjach poświęconych Pikowi i zapewne jego szacunki powtarzali późniejsi komentatorzy twórczości Mirandoli. Z kolei spokrewniony 
samym czasie właściwie wygasa twórczość artystyczna Pika - trudno bowiem zaliczyć do osiągnięć literackich wydane w tym czasie utwory dla dzieci, a uzasadnienie podjęcia pracy nad sennikiem lub antologią powinszowań na wszelkie okazje może odwoływać się wyłącznie do spraw finansowych.

Złośliwość losu objawia się w tym, że tak, jak zapomniano o Liber tristium Pika, tak też kurz pokrył przekłady poetyckie, którym przypisywał pewną wartość, zaś głównym tytułem do sławy stają się tłumaczenia arcydzieł literatury światowej, a więc dorobek ostatnich lat życia, którego Pik nie cenił.

\section{Produkcja translatorska}

Czy w tych warunkach możliwa była refleksja nad własnym warsztatem tłumacza? Bez wątpienia Pik obdarzony był umysłem głęboko krytycznym i byłoby zdecydowanie krzywdzące posądzenie go o brak namysłu nad własną pracą tylko na podstawie braku sformułowanego w specjalistycznych terminach programu. Podnosząc temat świadomości teoretycznej Mirandoli warto skierować uwagę na te utwory w jego dorobku translatorskim, które przełożył ze względu na osobiste preferencje. Grupę szczególną stanowią tu dzieła poetyckie. Ponieważ bibliografia narodowa nie podaje pełnego ich zestawienia, ani nie zawiera danych pozwalających na określenie, kiedy tłumaczenia powstawały ${ }^{12}$, pozostanie mi tu poprzestać na stwierdzeniu wzajemnego oddziaływania praktyki twórczej i działalności przekładowej, których zwornikiem była eksploracja poetyki impresjonizmu lirycznego. Nie bez znaczenia jest więc fakt, że pierwszy znany komentarz do twórczości translatorskiej umieścił Pik w debiutanckim tomie Liber tristium:

Tłumacz jest ojczymem dzieła, którego ojciec umarł lub wyjechał.

Pocałunki ojczyma są zimne ${ }^{\mathrm{r} 3}$.

Poddać go należy zabiegom interpretacyjnym właściwym badaniom form poetyckich. Decyduje o tym nie tylko miejsce publikacji, ale przede wszystkim poetyka, w jakiej utrzymany jest ten fragment. Operuje on bowiem językiem konceptu i paradoksu, który tworzy dominujący ton dojrzałej twórczości prozatorskiej Pika, ale przenika także wczesne tomy liryczne. Paradoksalność i dziwność wyraża tu przede

z nim Jerzy Pilecki, polemizując z Grzegorzem Sinko, mówi aż o 300 tomach („Odrodzenie” 1949, nr 5, s. 8.). Natomiast Nowy Korbut wykazuje 85 osobnych pozycji książkowych. Nie mając możliwości przeliczenia na arkusze wydawnicze przekładów dokonanych przez krośnieńskiego literata, można jednak bez wątpliwości uznać kalkulację Płomieńskiego za mocno przesadzoną i przyjąć ją za element legendy Pika, co nie zmienia faktu, że pracował on niezwykle intensywnie, a ilość wydanych tomów jest imponująca.

12 Dokładna kwerenda w czasopismach, której celem byłoby sporządzenie kompletnej bibliografii tłumaczeń utworów lirycznych i publicystycznych Pika powinna stać się zadaniem twórców monografii dorobku tego pisarza. 
wszystkim pointa wieńcząca koncept: zimny pocałunek. Wyrazy miłości, czułości, które kieruje tłumacz ku dziełu, stają się zimne, więc nieczułe i beznamiętne. Dlaczego? Czy dlatego, że zdaje sobie sprawę, że jest tylko ojczymem, nie ojcem, który nigdy nie będzie się cieszył przywilejami ojca? A może dlatego, że zmaganie z cudzym dziełem-dzieckiem łączy przeżywanie zauroczenia i pragnienia bliskości z odrzuceniem, daremnością trudu rodzącymi nienawiśćc Tu zapewne należy zaprzestać snucia domysłów i powiązać ten dość enigmatyczny fragment z bogatym światem refleksji nad związkiem twórczości własnej i przekładowej, w którym metafora przybranego ojcostwa zajmuje poczesne miejsce.

Nieco inaczej praktykę translacyjną Pika oświetla wyznanie artysty zamieszczone w liście do przyjaciela. W I9I4 roku Mirandola pisał do Wilhelma Feldmana:

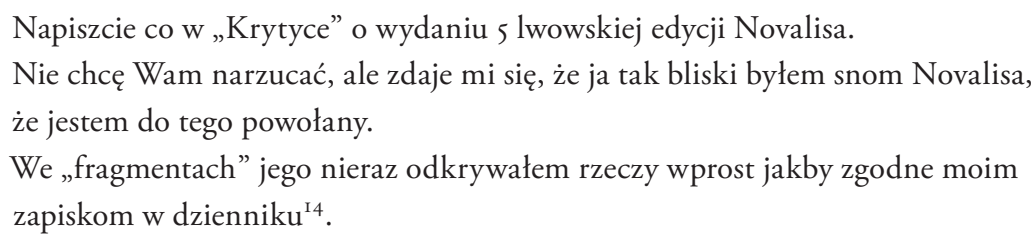

Przypis edytora wyjaśnia kontekst: piąta edycja Dziet Novalisa miała się ukazać w tłumaczeniu Pika nakładem J. Mortkowicza. Jak podaje Jacek Trznadel ${ }^{15}$, Mirandola przełożył cały dorobek Novalisa i jedynie wybuch wojny uniemożliwił dokończenie przedsięwzięcia wydawniczego. Świadczyłoby to o rzeczywiście niezwykle bliskim związku tłumacza z przekładanym autorem. Relację tę charakteryzuje Pik na dwa sposoby. Najpierw mówi metaforycznie, że został powołany do podjęcia tego zadania, gdyż bliski był snom poety. Metafizyczna sankcja jego przekładowej działalności podbudowana zostaje niewyjaśnialnym związkiem duchowym, który objawia się poprzez kontakt w snach. Drugie zdanie dopowiada informacje konkretne: Pik, czytając fragmenty poetyckie Novalisa, odnajduje passusy podobne do zapisków w swoim dzienniku. Dziennik Pika - o ile istniał - nigdy nie ujrzał światła dziennego, można jednak dostrzec podobieństwa między rozwijanym przez niemieckiego poetę gatunkiem romantycznego fragmentu, a zawartymi w dziale „Myśli” tomu Liber tristium krótkimi prozami poetyckimi - jedną z nich stanowi omawiany fragment.

Tłumaczenie ulubionych autorów jest więc porównywane do zimnego pocałunku ojczyma i spotkań z cudzym snem odczytanym we własnym dzienniku. Te dwie metafory zastępują program translatorski Pika i trzeba przyznać, że ich nośność semantyczna wynagradza niedostatek wypowiedzi dyskursywnych.

Późniejszy okres twórczości przekładowej, zwłaszcza po 1920 roku, charakteryzować można za pomocą analiz porównawczych i poprzez badanie recepcji tomów

\footnotetext{
14 Listy Franciszka Pika-Mirandoli do Wilhelma Feldmana w zbiorach biblioteki Zaktadu Narodowego im. Ossolińskich, wstęp i oprac. Grzegorz Brodacki, „Czasopismo Zakładu Narodowego im. Ossolińskich" 2012 (z. 22), s. 240.

15 J. Trznadel, dz. cyt.
} 
odstawianych przez Pika do wydawnictw. W pierwszym wypadku wiązałoby się to nie tylko z koniecznością zestawienia z oryginałem i innymi tłumaczeniami polskimi, ale także z dostępnymi w epoce tłumaczeniami na inne języki europejskie, bowiem Mirandola jest autorem przekładów dzieł w oryginale napisanych w języku francuskim, niemieckim $i$ angielskim oraz $w$ językach skandynawskich (norweskim, szwedzkim, duńskim), choć ich znajomość posiadał w stopniu bardzo zróżnicowanym. Biorąc pod uwagę obfitość dorobku translatorskiego Pika i konieczność prowadzenia tego typu badań nad każdym utworem osobno, trzeba uznać podjęcie takich analiz za wyzwanie przekraczające zakres tego szkicu. Jednocześnie, zważywszy na pośpiech towarzyszący pracy Pika, w wielu wypadkach wydaje się to zadaniem o sporym ryzyku niepowodzenia. Badacz często prowadziłby drobiazgowe analizy fragmentów w kilku językach, tymczasem na ich przełożenie Pik mógł poświęcić zaledwie kwadrans. Choć trafność decyzji translatorycznych nie zależy bezpośrednio od tempa ich podejmowania, ostatecznie mogłoby się okazać, że wynikiem wszelkich komparatystycznych analiz jest stwierdzenie mocnego piętna stylu Pika odciśniętego na języku oryginału. Zagadnienie to rozpoznała wcześniej krytyka literacka i nazwała „mirandolizacją" przekładu'16, czyniąc z niego powód wystarczający, by Pikowi odmówić wszelkich kompetencji.

\title{
Mirandolizacja przektadu
}

W meritum spraw dawnych i nieuchwytnych wprowadza nas w swoim wspomnieniu o Piku Jerzy Płomieński:

\begin{abstract}
Zapomniany wtedy jako twórca, a jako tłumacz zaszczuwany wprost przez konkurujących z nim w tej dziedzinie pisarzy, wegetował w fatalnych warunkach materialnych, bliskich nędzy. Mirandola nie reagował na zorganizowane kampanie, brutalnie napastliwe, skierowane przeciw jedynemu źródłu jego zarobkowania, to jest pracy przekładowej. Martwiły go głęboko te ohydne napaści prasowe, ale czuł się wobec nich bezbronny. Milczał z właściwą mu delikatnością, zamiast wysmagać inspirowaną przez konkurencyjne pióra chuliganerię pismacką, rozzuchwaloną bezkarnością swoich, anonimowych przeważnie (choć nie tylko anonimowych) ataków na starego pisarza. (...) Nakładcy korzystali z jego trudnego położenia, to jest z dokuczliwych grymasów prasy, które towarzyszyły benedyktyńskiej pracy przekładowej Mirandoli, traktując go niby debiutanta i płacąc mu najniższe stawki. (...)
\end{abstract}

16 Termin zaczerpnąłem z pracy Płomieńskiego, Franciszek Pik-Mirandola, [w:] tegoż, Twórcy bez masek, Warszawa 1956, s. 23. Płomieński zapewne czyni tu aluzję do artykułu Gabriela Karskiego, w którym autor wzywa do „respektu wobec oryginałów i zaprzestania praktyk samowolnego deformowania ich”, a praktykujących ten proceder tłumaczów nazywa „mirandolistami” i zachęca do „odpowiedniego ich zawstydzania”. (G. Karski, Stajnia Augiasza. O poziom literatury przektadowej, „Wiadomości Literackie” 1925 (R. II), nr 9 (6I), s. I. 
Wystąpiłem wreszcie kilkakrotnie z literacką kampanią w obronie przekładów Mirandoli przeciw skoalizowanym wrogom prasowym tępionego przez nich bezceremonialnie starego pisarza, którzy - o dziwo! - zamilkli na dłuższy $\operatorname{czas}^{17}$.

Nieco więcej światła rzuca Płomieński na kampanię przeciw Pikowi w artykule biograficznym opublikowanym w „Przeglądzie Humanistycznym”:

Przed kilku laty skoalizowana mafia literacka i bezimienny legion reporterskich wzmiankarzy wystąpił z kampanią przeciw jego tłumaczeniom. Przekreślono lekkomyślnie jego wartościowy, ilościowo gigantyczny dorobek przekładowy w imię nieodpowiedzialnej manii ryczałtowego myślenia i wartościowania, kolportując krzywdzącą plotkę, że Mirandola tłumaczy jedynie z języka niemieckiego, nie zna bowiem obcych języków. Panowie Piwiński i G. Karski, nie zadawszy sobie trudu poznania bogatego repertuaru jego pięknych przekładów, na podstawie jednego czy dwóch w nędzy uskutecznionych, i dlatego istotnie niedociągniętych, a nawet niechlujnych tłumaczeń, wydali drakoński sąd nad całością pracy i zawodowymi kwalifikacjami tłumacza. Mirandola nie protestował, nie bronił się, gdy demagogiczna niekompetencja, pasożytująca w wielu redakcjach, brutalnie ośmieszała jego pracę. Nigdy nie był człowiekiem walki ${ }^{18}$.

Płomieński, przyjaciel zmarłego poety, relacjonuje przebieg kampanii przeciw Mirandoli, rozpisując role: sobie przyznał maskę szlachetnego obrońcy, Pikowi bezbronnego i szlachetnego człowieka pracy, wokół którego zgromadziły się podłe hieny węszące łatwe zwycięstwo. Aby zajrzeć pod owe maski, warto poznać sądy wywołanych z nazwiska krytyków: Piwińskiego i Karskiego. Leon Piwiński w recenzji przekładu Księgi dżungli opublikowanej w „Przeglądzie Warszawskim” zestawia przekład Pika z oryginałem oraz dwoma innymi tłumaczeniami: wcześniejszym, polskim Józefa Czekalskiego oraz francuskim. Wytyka Pikowi najpierw spolszczenie imion postaci oraz tłumaczenie prozą motta książki w oryginale będącego wierszem, głównym zarzutem jest jednak to, że:

Nie czuł stylu Kiplinga i dał właściwie nie przekład, lecz parafrazę we własnym stylu. Szczególniej często tłumacz używa zaimków ,jakiś” lub „jakowyś”, w których najwidoczniej się lubuje; tymczasem Kipling, najkonkretniejszy z pisarzy, nigdy w podobnych przypadkach tych słów nie używa, bo on zawsze wie ,jakie” jest to, o czym pisze. (...) Parafrazowanie stylu posuwa się tak daleko, że tłumacz narzuca autorowi swoje własne obrazy tam, gdzie autor w ogóle nie myślał o żadnym obrazowaniu. Autor notuje, że w otworze owej wilczej jamy „świecił księżyc”: the moon shone; tłumacz zaś daje od siebie taki obraz: „do jamy zaglądała pyzata twarz miesiąca”. Przykładów podobnych można by zacytować tysiące, gdyż na jednej

17 J. Płomieński, Twórcy bez masek, dz. cyt., s. 23-24.

18 J. Płomieński, Franciszek Mirandola, „Przegląd Humanistyczny” 1930 (R. 5), nr 4/5, s. 517. 
stronie tłumaczenia jest ich więcej, niż mogłem przytoczyć. Słowem mamy tu do czynienia nie z tłumaczeniem Kiplinga, lecz z transpozycją jego prozy na styl gorszych pisarzy Młodej Polski ${ }^{\text {I9 }}$.

Leon Piwiński był w roku 1922 trzydziestotrzyletnim młodym krytykiem literackim, na co dzień pracującym jako urzędnik w Ministerstwie Pracy i Opieki Społecznej. Argumenty filologiczne Piwińskiego są słuszne, wyłożone rzeczowo i poparte odpowiednim materiałem dowodowym. Ciosem niezasłużonym było zepchnięcie tłumaczenia Pika w czeluść, która właśnie się zamykała nad dziedzictwem Młodej Polski uznanym u zarania drugiej Rzeczpospolitej za tradycję niechcianą. Wkład Pika - mógłby odrzec jego adwokat - nie był generycznym produktem moderny, był jego autorskim dorobkiem, poczytywać go należy za zdobycz kultury polskiej.

Wypowiedź Gabriela Karskiego, utrzymana w felietonowym tonie, powiela część zarzutów na temat poziomu przekładów:

Śród przekładów z literatury francuskiej wymienić trzeba przede wszystkim powieść Rollanda Colas Breugnon w tłumaczeniu p F. Mirandoli, który zaiste zbyt swobodnie sobie poczyna, przekręcając $i$ „uzupełniając” tekst autora; cechuje go przy tym niedopuszczalne niedbalstwo oraz szereg nieporozumień, lapsusów i „gaff”, nieraz wręcz komicznych, a świadczących o nietęgiej znajomości języka. Toteż przekład p. Mirandoli, z pozoru pełen zaciętości, w gruncie rzeczy tak się ma do pierwowzoru, jak np. tuzinkowe instrumenty, wyrabiane przez fabrykę „Neu-Kremona”, mają się do autentycznych „Stradivariusów” i „Amatich”.

Zbytnia swoboda przekładu połączona z pomyłkami wynikającymi z pośpiechu to para zarzutów, która będzie się pojawiać często. W pewien sposób charakteryzuje ona sytuację Pika. Jeśli swobodne podejście do oryginału zarzuca się artyście wybitnemu, to zaraz potem pojawia się radość z dzieła niemal rodzimego, bo zrodzonego ze spotkania dwóch geniuszów. Pośpiech i jego opłakane skutki łatwo wówczas wybaczyć. Co innego, gdy na swobodę poważy się nędzny wyrobnik, ktoś, kto wraz z całym swym pokoleniem dekadenckich pięknoduchów i nerwowców powinien już nie istnieć, a przynajmniej milczeć.

Odmawianie Pikowi prawa do swobody twórczej było deprecjacją jego artystycznego talentu nawet jeśli wynikało z umiłowania oryginału lub obrony prawideł rzemiosła, zdarzały się jednak recenzje wręcz miażdżące, utrzymane w tonacji serio, odbierające tłumaczowi podstawowy tytuł do wykonywania zawodu. Za taką z pewnością można uznać wypowiedź krytyczną Kazimierza Króla. Stanowi ona zbiorcze omówienie czterech tłumaczeń Mirandoli, którego zasadniczą część wypełnia zestawienie błędów

19 L. Piwiński, Kronika. Przektady i studia z literatur obcych, „Przegląd Warszawski” 1922, nr I3, s. II4-II5.

20 G. Karski, Stajnia Augiasza. O poziom literatury przektadowej, „Wiadomości Literackie” 1925, nr 9, s. I. 
językowych owych przekładów. Wyliczone są więc wszystkie grzechy Pika: „czystej wody germanizmy”, „wyrażenia pobudzające Polaka do serdecznego śmiechu”, błędy składni, frazeologii, leksyki, niestosowności stylistyczne, naleciałości gwarowe, niepotrzebne popisy, bezkrytyczne stosowanie partykuł itd. Całość zaś zmierza do konkluzji:

Zebrałem tutaj część swoich spostrzeżeń, dowodzących aż nadto wyraźnie, że p. F. Mirandola nie należy do pisarzy władających dobrze polszczyzną. To samo trzeba powiedzieć o licznych w jego opracowaniu książeczkach dla dzieci, wydawanych przez firmy lwowskie: są one napisane przeważnie takim językiem, że szanujące się rodziny polskie powinny by ich po prostu unikać przez wzgląd na dobro dzieci. Redakcja „Biblioteki Laureatów Nobla” powierzyła panu M. przekład całego już szeregu arcydzieł; z przykrością zaznaczam, że stało się to z niezmierną szkodą nie tylko dla publiczności polskiej, lecz niewątpliwie i dla autorów oryginałów. (...) Idzie o obronę zagrożonego mienia narodowego - o tępienie szkodnictwa ${ }^{2 I}$.

Po strzale oddanym z tak ciężkiego działa niewiele mogły zdziałać interwencje nawet najszlachetniejszych przyjaciół. Na szczęście wielu recenzentów znacznie przychylniej traktowało autorski wkład Pika, widząc w nim twórczą interpretację oryginału. O krytykowanym powyżej dziele znacznie bardzie stonowaną opinię wyraził Stanisław Wasylewski:

Już pierwszy tom wydawnictwa [Biblioteka Laureatów Nobla] Colas Breugnon Rollanda pojawił się w przekładzie Mirandoli. Czyniono mu zarzuty, częściowo słuszne, z racji nadmiernej swobody w spolszczeniu oryginału. Niemniej jednak ten rozkochany w dobrym winie stolarz burgundzki wychodzi w interpretacji doskonale.

I dalej o Mirandoli jako tłumaczu Maeterlincka:

Wiernie, czasem nazbyt wiernie tłumaczył swego ukochanego pisarza. W uzyskaniu doskonałości przekładczej i owej umiejętności transformacji w styl autora szkodził mu trochę fakt, że sam był poetą, któremu było trudno wyrzec się własnej indywidualności i formy. Ważyła tu epoka, wzgl. szkoła literacka, z której wyszedł. W pojęciu Młodej Polski proza opisowa nie zawsze miała należytą estymę, odnoszono się do niej często zbyt impresjonistycznie. Widać to również w Życiu pszczót. Ilekroć tłumaczowi przyjdzie odtworzyć ustęp o wysokim walorze poetyckim np. o locie miłosnym królowej, czy wspaniały, typowo impresjonistyczny pejzaż wsi normandzkiej, wówczas natrafił na swój żywioł, odtwarza go prześlicznie, z doskonałym odczuciem oryginału. W opisach rzeczowych, w których sam Maeterlinck stara się o drobiazgową dokładność, metoda impresji nie daje już tak dobrych rezultatów ${ }^{22}$.

21 K. Król, Poktosie, „Poradnik Językowy” 1927 (R. XXIII), z. 6-IO, s. 90.

22 S. Wasylewski, O ttumaczu Maeterlincka, [w:] Maurycy Maeterlinck, Życie pszczót, Wyd. 4, Poznań [I93I], s. III-IV. 
Gdy rozpatruje się recepcję przekładów Pika, wyraźnie odróżnia się diagnoza natury merytorycznej od nieakademickich aspektów działalności krytyki literackiej. Na tej pierwszej płaszczyźnie zasadniczo panuje zgoda - przekłady Mirandoli nie wytrzymywały krytyki mierzącej jakość dzieła na skali filologicznej dokładności, grzeszyły nader często lapsusami językowymi popełnianymi pod wpływem pośpiechu lub słabej znajomości języka oryginału, a inwencja ich autora nazbyt mocno kojarzyła się z poetyką jego własnych utworów. Oczywiście, spór ma podłoże fundamentalne, sprowadza się do różnicy w pojmowaniu powołania tłumacza albo jako dokładnego i pokornego sługi oryginału, albo jako artysty zmagającego się twórczo z cudzym dziełem. W pierwszym wypadku każde potknięcie i odejście od oryginału obniża rangę efektu pracy i spycha wyrobnika ku odmętom fuszerstwa, w drugim przypadku błędy można wybaczyć w imię sztuki i współczuć talentowi, który nie mógł się rozwiną́c ćn $^{23}$. Nawet jeśli polemiki tego rodzaju obfitowały w dosadne sformułowania, zasięg ich ograniczał się do kręgów fachowych, argumentacja zrozumiała była dla wąskiego kręgu specjalistów, poglądy te kolportowane były w pismach branżowych - filipikę Króla opublikował „Poradnik Językowy”.

Istnieje jednak i inna płaszczyzna recepcji - nazwijmy ją w uproszczeniu publicystyczno-społeczną. To dziedzina aktywnego weryfikowania aktualnego stanu kultury i jej adekwatności względem ideowych i politycznych postaw publiczności literackiej, czy - szerzej - społeczeństwa. Na tym polu Pik był na starcie przegrany, gdyż stawał do biegu z etykietą przybyszewszczyka, dekadenta i cygana. Magia tego zaszeregowania była tak silna, że nawet Płomieński widział w starszym pisarzu spadkobiercę przybyszewszczyzny, a pierwszy i jedyny monografista Janusz Herlaine najwyżej w jego autorskim dorobku cenił wczesne liryki. W efekcie po odzyskaniu niepodległości Pik nie został właściwie odczytany, a trwałość taksonomii nadal determinowała los jego dorobku w PRL.

Tymczasem recepcję dzieł Pika trzeba widzieć też jako fragment wielkiej dyskusji o bycie narodowym, a publikację niektórych przekładów jako głos do tej dyskusji świadomie dodany. Bardzo symptomatyczny wydaje się tu spór o ocenę przekładu Germinalu Zoli. Mirandola dokonał go w latach swojego szczytowego zaangażowania w działalność polityczną po stronie lewicy. Przekładał powieść-manifest w tak brzemiennym w wydarzenia roku 1905. Praca ta była artystyczną ekspresją społecznego

23 Pomijam tu kwestię podziału kompetencji w procesie wydawniczym, choć znający się na rzeczy nie mieli wątpliwości, że obwinianie wyłącznie Pika jest niewłaściwe. Z. Dębicki stwierdzał: Przekład tego niewatpliwego arcydzieta [Colas Breugnon] wyszedt spod pióra Franciszka Mirandoli. Ttumacz szczęśliwie pokonat wszelkie trudności. Na dobro poety, który nie żatowat swego czasu, zapisać należy tę pracę mozolna, wymagająca ciagtej, nieustannej troskliwości o umiejętne zachowanie tonu i barwy tego przedziwnego opowiadania, przesyconego zapachem wina i Montaigne'owska pogodna filozofia. życia. Szto tu niemal o każdy wyraz, o każdy btysk humoru, o każdy uśmiech. Mirandola nic z tego nie uronit. Z catym pietyzmem cztowieka znającego wartość sztuki, dla tego dzieta, pracę swoją wykonat i gdyby nie ciężkie grzechy korekty, która nie dopilnowata należycie wydania, mielibyśmy przed soba książkę bez zarzutu, godna zaliczenia jej pomiędzy wzorowe przektady, jakich tak mato posiadamy. (Z. Dębicki, Biblioteka laureatów Nobla, „Kurier Warszawski” I92I (R. IOI), nr 314.). 
zaangażowania - aktem podobnym do wywieszenia podczas demonstracji czerwonego sztandaru na Sukiennicach. W tych okolicznościach pierwszy recenzent pochwalił przekład: Chwila obecna przypomniata najpewniej wydawcom mistrzowskie dzieto Zoli. Pomimo swego specjalnego przeznaczenia, warte byto ono ponownego przektadu, zwłaszcza że pierwszy wyróżniat się niechlujstwem ${ }^{24}$.

Po drugiej wojnie światowej pojawiła się pokusa, aby z Pika zrobić męczennika ludu pracującego, ale znowu przeszkodziła w tym etykieta estety, pięknoducha i dekadenta. Czujność rewolucyjna inspirowała Grzegorza Sinko do wezwania:

aby przekłady tego tłumacza znikły wreszcie z naszego rynku wydawniczego. Germinal należy zresztą do bardziej udanych jego przyswojeń, ale i w nim dają się przykro odczuwać nieznośne, właściwe Mirandoli odwrócenia w szyku zdań, nadużywanie ulubionego przezeń „jeno”, terminy górnicze wzięte z niemieckiego lub utworzone dowolnie, wskazujące na robotę pośpieszną i niedokładną ${ }^{25}$.

Zgodnie z katalogiem zwykle używanych przeciw Pikowi zarzutów: znowu niezdolność do oddania konkretu choćby poprzez właściwą terminologię, młodopolska maniera, niedokładność i pośpiech. Czymś nowym jest jednak sposób, w jaki przeciwstawił się tej krytyce Jerzy Pilecki ${ }^{26}$, który nie bronił filologicznych aspektów dzieła, nie wydobywał na plan pierwszy zalet artystycznej interpretacji oryginału, lecz domagał się poszanowania pracy tłumacza. Wartości nabrał sam fakt, że Pik siadał przy biurku i godzinami przekładał cudze słowa na język polski? Że był robotnikiem pióra?

Można uznać postawę Pileckiego za przejaw życia literackiego w przeddzień szczecińskiego zjazdu literatów w 1949 roku, na którym zadekretowano program sztuki socrealistycznej. Uwzględniwszy jednak, że Pilecki był spokrewniony z Pikiem ${ }^{27}$, że gromadził rodzinne dokumenty związane z pisarzem i publikował na temat jego spuścizny rozprawy historyczne, czytelnik zdoła usłyszeć $\mathrm{w}$ tym proteście ton autentyczny, wołanie o ratunek dla wyśmiewanego i odsuwanego na margines twórcy, wyrażone jedynym dostępnym wówczas językiem.

\section{Sprawa Pika}

Pilecki potrąca strunę, która pobrzmiewała cały czas na dnie sporu o tłumaczenia Mirandoli - wystawia na plan pierwszy owe warunki pracy, powodujące pośpiech i błędy. Był w tym, oczywiście, współudział Mirandoli, który nie potrafił zadbać o swoje interesy, jednak aspektem sprawy, który przemilczano jako oczywisty i wstydliwy,

24 W. Jabłonowski, „Książka” 1906 (R. VI), s. 325.

25 G. Sinko, Abyśmy nie zapomnieli... (czytając znowu „Germinala” Emila Zoli), „Dziennik Literacki” 1948, $\mathrm{nr} 49$ (92), s. 2.

26 J. Pilecki, O szacunek dla trudu pisarskiego, dz. cyt.

27 Matka Jerzego Pileckiego, Honorata Pik, była ciotką Franciszka Pika. 
wydaje się uwikłanie w kapitalistyczne stosunki produkcji dóbr kultury. W przypisie Herlaine bez ogródek wypowiada opinię na temat lwowskiego wydawcy:

\begin{abstract}
„Renaissance” nie tylko robił umowę na warunkach przypominających warunki, $\mathrm{w}$ jakich pracowali nieletni po fabrykach zanim w to wtrąciło się ustawodawstwo społeczne, ale nawet tych zobowiązań nie honorował ${ }^{28}$.
\end{abstract}

Płomieński pisze wprost, że wystąpienia krytyczne przeciw Mirandoli inspirowała konkurencja zarobkowa, a najwięcej korzystali na niej wydawcy. Kampania krytyków Mirandoli staje się tym samym kwestią nie tyle estetyczną, co społeczną, zyskuje rangę „Sprawy”.

W tych kategoriach swoją działalność pojmował sam artysta. W wydanej w I905 roku, otwarcie deklarującą udział w walce proletariatu broszurze Sztuka a lud Pik zaznaczał: Cate dzieje sztuki wykazuja nam jej ścista zależność od warunków ekonomicz$n y c h^{29}$. Tam też umieścił wyliczenie, które mógłby dopełnić własnym przykładem:

Zakopany głęboko pod ziemią w suterenach, pracujący po całych dniach w kurzu, dymie i zaduchu robotnik fabryczny, urzędnik zgarbiony nad aktami w mrocznej kancelarii, konduktor tramwaju stojący przez kilkanaście godzin dziennie na trzęsącej się wśród zgiełku i zgrzytu podłodze wozu, praczka dławiąca się cały dzień wyziewami mydła i pary, dziennikarz w zadymionej redakcji, zecer wypatrujący oczy nad kasztą, słowem każdy chyba proletariusz, chyba w marzeniach sennych, chyba w fantazji odnaleźć może wyrażenia piękne, miłe, ciche ${ }^{30}$.

Toż to obrazek z życia Pika-Mirandoli. We wspomnieniu z pierwszej wizyty u artysty w Krakowie Płomieński zanotował obraz jego gabinetu: Na stole ktębity się rozrzucone beztadnie nierówne sterty książek, karty rękopisów i dtugie taśmy świeżej korekty $^{31}$. Za tym biurkiem siadał do pracy. W liście do Władysława Orkana opisał warunki pracy w mieszkaniu na ul. Św. Gertrudy w Krakowie w 1904 roku:

Kochany Poeto! Gdym list wasz serdeczny czytał, było w pokoju $8^{\circ}$ ciepła, a w kuchni brak zupełny węgla, jakoteż prawie że wcale [nieczytelne] na... kolację. (obiad był zrobiony... olej i ziemniaki). Oto krótki sonet prozą życia napisany, oto wszystko prawie, co się da powiedzieć o moim „ja” przestrzennym i czasowym ${ }^{32}$.

Zagrzebany w papierach, w stosie zleconych książek, marzył o dwutomowej powieści, która przywróciłaby jego nazwisko życiu kulturalnemu, marzył o słowach cichych

28 J. Herlanine, dz. cyt., s. 28.

29 F. Pik Mirandola, Sztuka a lud, Kraków 1905, s. I4.

30 Tamże, s. 5.

31 J. Płomieński, dz. cyt., s. 25.

32 Rękopis listu do W. Orkana z 3I marca 1904 roku ze zbiorów BJ. 
i pięknych, o pisaniu wierszy. Tymczasem dopisywał kolejny rozdział do opowieści, która ciągnęła się już od wielu lat. Jej treścią jest los pisarzy polskich.

Twórczość artystyczna nigdy nie zapewniała dostatniego chleba. Już osiemnastowieczne pamiętniki znanych autorów rzadko koncentrują się na ich zatrudnieniach literackich, jakby podkreślając ich marginalne znaczenie dla biegu życia w porównaniu z osiągnięciami w karierze urzędniczej lub politycznej. Nieszczęściem rodzącej się klasy inteligenckiej było nienadążanie procesów modernizujących ustrój społeczny i gospodarkę za zmianami idei kształtujących edukację. Słowem, najpierw puszczano w obieg między młode głowy świeże idee, a potem okazywało się, że rynek pracy potrzebuje woźniców, drwali, ślusarzy i cieśli, a nie nauczycieli, bo właśnie edukacji zaborca zbytnio nie pragnął. Nie wykwalifikowanych urzędników - gdyż przedstawiciele podbitej nacji na wyższych stopniach administracji powinni wszak posiadać jedną kwalifikację: lojalność. Nie oficerów wreszcie, bo w armii nie można służyć Polsce. Inżynierowie, dopóki przemysł nie zaczą ich potrzebować, również skazani byli na poniewierkę.

W drugiej połowie wieku XVIII absolwent postępowego Collegium Nobillium Kajetan Węgierski wygłosił przed wizytującym placówkę monarchą mowę o budowaniu nowego społeczeństwa na fundamencie wykształconej młodzieży. Ostatecznie karierę rozpoczął od godności tytularnej szambelana i posady kancelisty, a zawód literacki porzucił, by utrzymywać się z gry w karty. W swej twórczości opisywał kariery nieuków, fortuny oszustów i awanse dzięki stręczeniu własnych żon. Węgierski pozostawił po sobie taką oto parafrazę listu Woltera:

Prawda, że mimo zasług a wiele urzędów,

Lecz może na ukryty przymiot nie ma względów?

Może Cycero jaki lub Wergili nowy

Miesza wapno i cegły nosi do budowy

Albo, niewolniczymi obciążon roboty,

Nad przepisaniem cudzej męczy się ramoty ${ }^{33}$

Po ponad stu latach motyw ten wraca w artykule Aleksandra Świętochowskiego:

Literatura polska w tej chwili geniusza nie posiada. Starzy olbrzymi pomarli - nowi się jeszcze nie narodzili. A może ich już natura nieraz stworzyła, ale warunki nie pozwoliły im się rozwinąć. (...) Walka o byt - nędza - kropla roztworu bromowego nie w porę dana - kułak w głowę - wszystko to pojedynczo lub razem wystarczyć może do tego, ażeby Kopernik lub Mickiewicz w kolebce został konduktorem drogowym lub organistą w późniejszym życiu. Dawniej stada umysłów dzielniejszych odlatywały daleko i wyrabiały sobie skrzydła w obszernych przestworach obcego świata, teraz zamieniony instynkt wszystkie zatrzymuje na rodzinnym ciasnym podwórzu. Wielka to korzyść dla gospodarstwa krajowego, ale kto wie, czy orzeł

33 Kajetan Węgierski, Poezje wybrane, wstęp i oprac. Juliusz Gomulicki, Warszawa 1981, s. 7. 
z obciętymi skrzydłami na śmieciach jak kogut nie grzebie, kur do ziaren nie zwołuje i na odmianę nie pieje - zamiast szybować pod obłokami?34

Jeśli Cycero miesza wapno, Wergiliusz nosi cegły, Mickiewicz został konduktorem, to kim mógł stać się pisarz w niepoetycznych latach węgla i pary? Odpowiedź brzmi: literatem.

Literat to płód czysto Warszawski, powstał z końcem zeszłego stulecia i dotąd nigdzie nie dał się przeszczepić poza rogatkami stolicy, chyba czasem w lichym naśladownictwie i spaczonej parodii. W innych częściach Polski bywali poeci, uczeni, pisarze - nie bywało literatów z zawodu, z cechu w właściwym tego słowa, czyli ludzi, w których żyłach płynie atrament, którzy ze wszystkiego gotowi zrobić książkę lub artykuł, którzy nie znają innego pola działania, którzy nawet w stosunkach towarzyskich są literaturą chodzącą. Do właściwości literata należy to, że się nie przywiązuje wyłącznie do jednego przedmiotu, że nie jest specjalistą, ale pewną wszechstronność łączy z nieuniknioną powierzchownością. Literat może istnieć tylko w stolicy, i potrzebuje dwóch warunków atmosfery literackiej: dworu, a w jego braku salonu literackiego i potrzebuje takich stosunków, które na polu literackim zabezpieczają jeśli nie karierę to przynajmniej środki utrzymania ${ }^{35}$.

Literat jest pracownikiem w fabryce tekstów, produktywnym dyletantem, dającym dobra w akceptowalnej jakości i świeżości. Lucjan Siemieński nie widzi w tym znaku czasu znamion upadku ${ }^{36}$. Widzi szansę znalezienia w masie nowego mecenasa, który gotów jest płacić, niekoniecznie w zamian za pochlebstwo, gdyż przewodnicy mas wskażą wartościowe dzieła, oddzielą pokarmy pożywne od trujących i lichych. Widzi wszakże i strony ujemne, a wśród nich przerażająca, nieskończoną liczbę sypiących się $k s i a \dot{z} e k^{37}$ oraz nadmierne eksploatowanie talentu, który rozmienia się na drobne, osłabia:

Pośpiech w robocie, korzyści z przyśpieszonej produkcji, powab rzucania się w różne przedsiębiorstwa wydawnicze - wszystko to przyczynia się do zużycia sił umysłowych pisarza, geniusz spada do miary talentu, talent rozbryzguje się w nędzne ramotki $\mathrm{i}^{38}$.

Dlatego Siemieński apeluje, by „pokup” nie był miarą wartości literatury, by służyła ona oświecaniu społeczeństwa a nie schlebianiu mu.

Ileż optymizmu Siemieńskiego podzielał Pik! Autor Warszawianki 1905 roku wierzył w lud, w imię proletariatu wkradł się do gmachu Sukiennic i wywiesił czerwony sztandar, co odpokutował ucieczką z miasta. Współpracował w tym czasie z „Naprzodem” i na

34 Poset prawdy, Najbliższa przysztość, „Prawda” I884, nr 26 (28 VI).

35 L. Dębicki, Kazimierz Wtadystaw Wójcicki, „Czas” 1879, nr I84.

36 L. Siemieński, Kilka rysów z literatury i spoteczeństwa od roku 1848-1858, tom I, Warszawa I859,

s. 44,45 .

37 Tamże, s. 46. 
jego łamach toczył kampanię o lepsze jutro ludu pracującego. Aby umożliwić robotnikom dostęp do prasy, skomponował słowniczek trudnych wyrazów, pisał opowiadania dla dzieci robotniczych, żył nadzieją, że już wkrótce pojawi się nowa, sprawiedliwsza i bogatsza kultura ludu pracującego. We wspomnianej już broszurce Sztuka a lud wyrażał wręcz pewność, że stanie się to nieodzownie, bo takie jest prawo pochodu dziejów.

Siemieński poglądy swe zweryfikował po rabacji galicyjskiej, Pik pozostał marzycielem. Marzycielem i literatem. Zgodnie z diagnozą zgorzkniałego romantyka sypał książkami i rozmieniał talent na drobne przedsięwzięcia, na senniki egipskie i nauczanie powinszowań. Życie jednak biegło swoim torem, dając Pikowi wybór między apteką a tłumaczeniem owych legendarnych dwustu tomów w osiem lat. Wybrał galerniczą pracę i marzenia - na marginesie życia budował swój byt mityczny.

Los Mirandoli stał się symbolem pełnym znaczenia. Po jego śmierci opublikowano 2I nekrologów! Jego debiut recenzowało ośmiu krytyków i jeśli zainteresowanie autorem mierzyć odzewem czasopism, to nigdy nie było ono większe. I nagle, niespodziewanie, po śmierci Pika okazuje się, że istniał, że jego sprawa na wierzchu.

Nekrologi, oprócz narzuconych konwenansem formułek, zawierają zazwyczaj skrócone sprawozdanie z życia i spraw zmarłego. Nie inaczej było tym razem. Powtarzano konwencjonalne pochwały, frazesy o talencie zabitym mrówczą pracą, o wyrobnictwie odbierającym godność artysty, o odchodzeniu pokolenia Młodej Polski. Uderzał jednak przede wszystkim zbieg okoliczności: Pik czekał na wykonanie eksmisji i na nagrodę za twórczość. Zmarł wkrótce po zgonie najbliższego przyjaciela Władysława Orkana. To jednak nie wszystko - obok nekrologu Pika zamieszczono pożegnanie Zofii Smreczyńskiej, córki Orkana, utalentowanej poetki, która - tak jak Mirandola - odeszła do wieczności 3 czerwca 1930 roku. I tu kolejny zbieg okoliczności - relacjonuję za Rajmundem Berglem:

Mamy jeszcze wszyscy w pamięci śmierć Wł. Orkana. Tuż po pogrzebie rozeszły się pogłoski, że zmarły żył w takiej biedzie, że nie stać go było nawet na sprawienie sobie choćby jednego garnituru porządniejszego przyodziewku, że dopiero województwo krakowskie wyasygnowało wdowie zapomogę na zakupno „śmiertelnej koszuli” wybitnemu poecie i powieściopisarzowi, znakomitemu publicyście, przy tym wysłużonemu oficerowi Legionów Polskich. Nie chcieliśmy tym pogłoskom dać wiary, wszakże na parę dni przed śmiercią był Orkan w Warszawie po odbiór przyznanej mu nagrody literackiej i nie sposób przypuścić, aby człowiekowi o tak skromnych wymaganiach tak szybko się znaczniejsza bądź co bądź kwota rozeszła. Lecz oto niedługo później dzienniki uchyliły rąbka tajemnicy. Orkan przyznanej mu nagrody znów nie dostał, bo w kasie zabrakło pieniędzy i dopiero obecnie kompetentne czynniki mają kłopot z rozwiązaniem problemu, czy niepobrane przez laureata pieniądze należy wypłacić wdowie, czy może je do nadzwyczajnych dochodów powrotem wliczyć3 ${ }^{39}$.

39 R. Bergel, Wyrobnicy ducha (w sprawie niedoli pisarzy polskich i ufundowania nagrody literackiej m. Krakowa), „Głos Narodu” 1930 (R. XXXVII), nr I79. 
Przypadkowych zbieżności było zbyt dużo. Sprawa Pika urosła do rangi problemu społecznego. Głosy oburzenia kierowano do polityków i do wyzyskiwaczy:

Czy naprawdę naród 30 milionowy, który stać na wiele rzeczy niepotrzebnych - nie może się zdobyć na usunięcie kompromitującego zjawiska, iż jego wybitni pisarze, zasłużeni dla kultury narodu, umierają w nędzy, a rodziny ich pozostają na łasce losu? ${ }^{40}$

Na literaturze i publicystyce naszej odbijają się te same wady „chlebodawców”, które nie pozwalają i robotnika polskiego stawiać w jednym rzędzie z zagranicznym. Boć przecież zastanawiającą jest rzeczą, iż ten polski robotnik, wyjeżdżający „na Saksy”, staje się nagle pracownikiem doskonałym. Chwalą go Francuzi, Niemcy, Amerykanie... Tylko przy polskim ekonomie jest on wciąż wałkoniem. (...) I my, literaci, publicyści, mamy również takich samych tu ekonomów. Marnujemy przy nich talenty, zdychamy z głodu i dajemy się dystansować kolegom zagranicznym - niekoniecznie z własnej winy ${ }^{41}$.

Czytelniku! Czytelniku! Spojrzyj: ani oryginalnym twórcą być nie można, ani nawet rzemieślnikiem! Tak czy inaczej czeka głód i śmierć w nędzy z wycieńczenia ${ }^{42}$.

Sumienie narodu drgnęło... i szybko wrócono do porządku dnia. Po zdawkowych pośmiertnych hołdach nie przyszedł czas na przemyślenie na serio dorobku Pika. Książka Herlaine’a nie wystarcza. Patrząc z dzisiejszej perspektywy, można przypuszczać, że szanse na ponowne odczytanie dzieła Pika były wtedy wysokie. Eksperymenty ekspresjonistów i awangardy otworzyły publiczność na jakości wcześniej u Pika ignorowane: groteskę, absurd, koncept, surrealizm. Opadała radość z odzyskania śmietnika i surowa refleksja nad naturą ostatniej wojny odsłaniała pole dla pacyfistycznych i egzystencjalnych dylematów krośnieńskiego artysty. Mogło się niemal każdego dnia okazać, że żyjący w zapomnieniu, niemal nędzy, przytłoczony pracą i pogrążający się w nałogu tłumacz wyraża sprawy ważne. Zwyciężyła zawiść? Przegrał walkę konkurencyjną? Nie udało się zedrzeć przeklętej etykietki?

Przyjaciel zmarłego, Stanisław Przybyszewski, miał podobno w zwyczaju mawiać przed wychyleniem kieliszka: Szopen, gdyby żył, to by pił. A kim byłby Mickiewicz, gdyby urodził się w Krośnie w I87I roku? Może aptekarzem. A może zostałby tłumaczem?

\section{Tryumf Mirandoli?}

Spojrzenie na cały, zamknięty już dorobek artysty pozwoliło dostrzec i wskazać do dziś ważną zasługę Pika:

40 B. Hertz, Losy pisarzy polskich. Kompromitujące spoteczeństwo stosunki, „Polska” 1930 (R.2) (wydanie AB), nr I5s, s. 9.

41 B. Hertz, Listyz Warszawy. Po zgonie Mirandoli-pisarze i ich ekonomowie, „Kurier Wileński” 1930 (R. 7), $\mathrm{nr}$ i36(1778), s. 3 . 
Troski i zdrowie słabe nie pozwoliły mu na większą skalę rozwinąć pracy literackiej, do której go predestynował talent wybitny. W twardej walce o życie, moc czasu i sił poświęca na pracę tłumacza, przyswajając czytelnictwu naszemu wiele cennych dzieł współczesnej literatury Zachodu ${ }^{43}$.

Niebawem przeszedł Mirandola do tłumaczeń z literatur obcych, kładąc w tej dziedzinie niepożyte zasługi. Tłumaczenia jego, zwłaszcza laureatów nagrody Nobla, stawiają mu trwały pomnik w literaturze polskiej ${ }^{44}$.

Nie ma człowieka inteligentnego w Polsce, który nie zawdzięczałby Franciszkowi Mirandoli poznania przynajmniej kilku wielkich pisarzy zagranicznych. Tłumaczył z niesłabnącą nigdy energią, tłumaczył dzieła wybitnych pisarzy francuskich, hiszpańskich, niemieckich i włoskich, i w tych swoich tłumaczeniach jakby się spieszył, jakby przeczuwał, że płomień jego życia niedługo zgaśnie i nie zdoła przed swoim społeczeństwem rozdzielić wszystkich skarbów literatury zagranicznej ${ }^{45}$.

Literatura polska straciła onegdaj wybitnego i gorliwego pracownika, który uprzystępnił narodowi polskiemu niezliczony szereg arcydzieł piśmiennictwa narodów zachodnich: Franciszka Pika-Mirandolę ${ }^{46}$.

Przyszły monografista, który zajmie się dotąd przygodnie tylko traktowaną historią literatury przekładowej u nas, wyznaczy mu w niej zapewne pozycję poważną ${ }^{47}$.

Recenzenci dostrzegli w olbrzymim dorobku translatorskim Pika autentyczną wartość. Ponownie decydowały okoliczności: czas i miejsce. Społeczeństwo polskie w pierwszych latach niepodległości cierpiało na wiele bolączek. Słabość rynku wydawniczego była przejawem instytucjonalnej zapaści kultury narodowej. Wieloletni brak organizacji wspierających twórców i niedbałość o wytworzenie szerokiej publiczności literackiej owocowały sytuacją, w której pustą przestrzeń zapełniały działania rynkowe obliczone na zysk. Nie zawsze były to inicjatywy szkodliwe, w sumie jednak obnażały one niedostatek kulturotwórczego, celowego i wytrwałego działania instytucji wytwarzanych przez wspólnotę. Jak pisał Stanisław Dzikowski:

Nasze środowiska czytelnicze podobne są nieraz do jakichś małych, podrzędnych stacyjek, na których zatrzymują się, zawsze z opóźnieniem, tylko pociągi wołowe, a wspaniałe i lśniące ekspresy przelatują tak szybko, że trudno je zauważyć. Ten

43 B. Pochmarski, Śp. Franiciszek Mirandola (Franciszek Pik), „Ilustrowany Kurier Codzienny” 1930, nr I48, s. 9.

44 J. Augustynowicz, Zgon Franciszka Pika-Mirandoli wybitnego literata, zmartego w skrajnej nędzy, „Dziennik Poznański” 1930 (R.72), nr I29, s. 3.

45 Bł, Franciszek Mirandolla, „Słowo Polskie” 1930 (R. XXXIV), nr I5I.

46 „Dziennik Lwowski” 1930 (R. V), nr I53, s. 7.

47 J. Płomieński, dz. cyt., „Rubikon”, s. 8o. 
wielki i nieustający ruch, ten strumień energii wiecznie żywej i twórczej, który przepływa przez wielki świat, który jednoczy w sobie wysiłki wszystkich narodów, w którym wyrażają się wielkie konflikty i wielkie zagadnienia, nie jest u nas zobrazowany systematycznie, z właściwą sobie logiką ${ }^{48}$.

Scalanie Polski, wieloetnicznej, wielojęzykowej wspólnoty, którą należało budować z tak różnych elementów, było w dużej mierze walką z chaosem, rozproszeniem kultury tak długo, uporczywie i agresywnie wcielanej w obręb innych organizmów narodowych. Jednocześnie do głosu dochodziły inne sąsiednie narody i zamieszkujące w granicach Rzeczpospolitej nacje, co podwyższało stan kulturowej niepewności i zmuszało do poszukiwania własnej tożsamości. Działanie Mirandoli pomagało jednoczyć mieszkańców odrodzonego państwa, miało w sobie i coś z apostolatu kulturalnego, i patriotycznej działalności polonizacyjnej wobec tradycji Zachodu. Przekładami swymi Pik osadzał odradzającą się Polskę w głównym nurcie kultury Europy. Ważny był wybór tekstów - Mirandoli w udziale przypadło przekładanie nie tekstów-satelit, a tekstów-gwiazd, a więc dzieł wyznaczających ścieżki kultury europejskiej.

Pik oddał więc niepowszednią przysługę swoim współczesnym, choć może z tego sobie sprawy nie zdawał. Był dzieckiem Młodej Polski, o której Kazimierz Wyka pisał: Pojęcie Europy literackiej jako wspólnoty bodźców literackich nie byto wówczas pustym dźwiękiem ${ }^{49}$. Kosmopolityzacji elit, globalizacji rynków towarzyszyła wymiana kulturowa na niespotykaną wcześniej skalę. W jej wyniku przekłady stawały się istotnym elementem życia literackiego. A że przekłady robił po swojemu? Tłumacz pracuje dla swojego czasu, nie dla przeszłości. Stawia lustra, w których przeglądają się światy - także jego wnętrze. W nich utrwala się jego byt - mit Pika-Mirandoli.

\section{Dopiski}

I. Tłumaczeni przez Pika Laforgue i Verlaine również zmarli w nędzy. Laforgue pożegnał się ze światem w wieku 27 lat, przeżywszy swą młodą żonę, również poetkę, o kilka miesięcy. Paul Verlaine żył dłużej, jednak ostatnie lata życia spędził w biedzie, był uzależniony od alkoholu, przeżywał ataki na tle nerwowym.

2. Tłumaczący autorów polskich na francuski Paul Cazin otrzymał za przetłumaczenie Pana Podfilipskiego Waysenhoffa honorarium, które nie wystarczyło na pokrycie zużytego papieru. Przekład Popiołów Żeromskiego proponowano mu bez dawania nadziei na wynagrodzenie ${ }^{\text {so }}$.

8 S. Dzikowski, Ttumaczenia i ttumaczenia, „Przegląd Literacki” 1930, nr 4, s. 2.

9 Tamże, s. 85.

50 D. Knysz-Tomaszewska, Paul Cazin - ttumacz prozy mtodopolskiej, [w:] Przektad literacki. Teoria, historia, wspótczesność, red. A. Nowicka-Jeżowa, D. Knysz-Tomaszewska, Warszawa 1997, s. 205-225. 
3. O Januszu Herlaine Agnieszka Fabiańska pisze w kontekście jego zainteresowania Pikiem-Mirandolą: W popadającym wówczas powoli w zapomnienie Herlainie odezwata się solidarność z owym poetą i ttumaczem podobnie jak on zapomnianym. Następnie badaczka cytuje słowa Herlaine’a zanotowane czterdzieści lat później: so lat przeżyte $w$ Polsce byto wegetacja ... opancerzonego żótwia wobec otaczajacego środowiska. Pracujacego bez gtosu i ze skrępowanymi rękami jak katorżnik na chleb tylko dla rodziny $i$ dla siebie. Jego biografię zamyka zaś opis: Po wojnie odsunąt się od życia utrzymując się ze skromnej posady ttumacza w jednej z ambasad. Pisat już tylko do szuflady, dając wyraz swym pogladom $w$ licznych polemikach $z$ artykutami drukowanymi we wspótczesnej prasie. Herlaine zmarł w 1973 roku $^{\text {s. }}$.

4. Liczne tłumaczenia Pika należą dziś do domeny publicznej, co oznacza, że już nie odnoszą się do nich prawa majątkowe autora i jego spadkobierców. W tej sytuacji użycie ich w celach komercyjnych, np. w celu reprodukcji książkowej, wiąże się jedynie z uiszczeniem odpowiednich opłat administracyjnych. Tym samym stanowią one tańszą alternatywę dla wydawców niż zlecenie nowego tłumaczenia. 
Pożytki z czytania nekrologów. Sprawa Pika Mirandoli

Twórczość autorska Franciszka Pika Mirandoli popadła w zapomnienie, do czego przysłużyła się przyklejona mu etykieta młodopolskiego estety, która pomija jego utwory prozą oraz wyrazy społecznego zaangażowania. Jednocześnie nieciesząca się w jego własnych oczach uznaniem praca przekładowa urasta do rangi rzeczywistej zasługi dla jego współczesnych i późniejszych pokoleń. Szczególnej wartości nabierają spolszczenia klasyków literatury światowej dokonywane przez Pika dla serii Biblioteka Laureatów Nobla, które odegrały ważną rolę w procesie integracji kultury odradzającego się państwa polskiego z wielkimi nurtami literatury europejskiej. Jednocześnie praca tłumacza wplątała Mirandolę w kapitalistyczne stosunki rynku literackiego, a ostatecznie w nędzę. Obserwatorzy upadku jego talentu pod wpływem przeciążenia pracą zarobkową po śmierci Pika nadali temu zdarzeniu wymiar symboliczny, dostrzegając w ubóstwie i zgonie pisarza znaki czasu i symbole losu inteligencji polskiej.

SŁOWA KLUCZOWE

Pik Mirandola, tłumacz, recepcja, inteligencja

\section{ABSTRACT}

Franciszek Pik's works have been ignored since he had been labeled a decadent and an aesthete. Thus his prose and political writings became totally forgotten despite the fact that their aesthetic value is generally approved. At the same time his translations are still very popular. Paradoxically, he is now renowned for the works that he attached little weight to himself, as he treated translation of Nobel prize winners' works as a source of income only. From the modern perspective, however, his translations appear to be both a link between European heritage and the culture of Poland reborn after over a century of political dependence and a showcase of how early capitalist market regulations interfered with the mission of the intelligentsia in the interwar period. The death of the translator had been recognized as a symbol of artists fate in the wake of commercial publishing.

KEYWORDS

Pik Mirandola, translator, reception, inteligentsia 